\title{
Pengembangan OSD (On Screen Display) dengan Penambahan Menu untuk Aplikasi pada Semi Autonomous Mobile Robot dengan Lengan untuk Mengambil Objek
}

\author{
Muhammad Saiful Hak, Ronny Mardiyanto, dan Suwito \\ Jurusan Teknik Elektro, Fakultas Teknologi Industri, Institut Teknologi Sepuluh Nopember (ITS) \\ Jl. Arief Rahman Hakim, Surabaya 60111 \\ e-mail: msaifulhak@gmail.com, ronny.mardiyanto@gmail.com, mas.suwito@gmail.com
}

\begin{abstract}
Abstrak-Tugas Akhir ini membahas pengembangan OSD (On Screen Display) dengan sistem FPV (First Person View) yang bertujuan untuk mendukung kinerja sebuah RC (Remote Control) atau mobile robot dengan cara mengambil data pada RC atau mobile robot tersebut. Penggunaan sensor pad a modul OSD ini terbatas, sehingga dilakukan sebuah pengembangan dengan penambahan pengkabelan dan pemrograman menggunakan kompiler Arduino. Dalam sistem ini, OSD yang dipakai adalah dua buah minimOSD yang telah dirancang dengan penambahan beberapa fitur menu sensor. Pada minimOSD yang pertama data GPS (Global Positioning System) berupa posisi lintang dan bujur didapat dari APM (ArduPilot Mega) yang diprogram menggunakan minimOSD extra. Pada minimOSD yang kedua didapat data sensor ultrasonik dan posisi lengan robot yang dikirim oleh Arduino Mega pada mobile robot menggunakan pengiriman serial. Sensor suhu, level baterai dan data waktu diperoleh dari penambahan pengkabelan pada pin-pin ATMega328. Hasil olah data sensor pada minimOSD pertama dan kedua yang berupa data visual digabung dan dikirim menuju layar monitor FPV menggunakan video transmiter. Animasi data yang ditampilkan mempunyai batas sebesar 256 data karakter, sehingga posisi lengan robot dan sensor ultrasonik hanya bisa digambarkan berupa perbandingan skala tingkatan dan data teks, sedangkan data sensor yang lain ditampilkan sesuai hasil olah data sebenarnya.
\end{abstract}

Kata Kunci- OSD (On Screen Display), FPV (First Person View), minimosd, remote control, APM (ArduPilot Mega), Arduino pro mini.

\section{PENDAHULUAN}

$\mathrm{P}$ EMANFAATAN media informasi saat ini semakin berkembang pesat dan tak lepas dari kehidupan manusia. Pemanfaatan informasi dalam bidang elektronika digunakan untuk memperoleh data-data seperti sensor atau data visual yang nantinya dapat dimonitoring secara real-time atau bisa dikatakan sebagai multi-modal feedback. Contoh dari pengambilan informasi ini seperti pada pengambilan data sensor oleh Arduino atau bisa juga oleh APM (ArduPilot Mega) yang nantinya diterjemahkan dalam bentuk visual menggunakan OSD (On Screen Display) dan ditransmisikan menggunakan sistem FPV (First Person View). Untuk mendukung kinerja sebuah $\mathrm{RC}$ atau mobile robot, maka digunakan modul OSD (On Screen Display) seabagai informasi data yang diambil oleh $\mathrm{RC}$ atau mobile robot tersebut. Informasi data yang diambil oleh sistem mobile robot ini akan diterjemahkan kedalam bentuk data visual pada OSD tersebut yang nantinya akan ditransmisikan bersama data visual kamera menuju layar monitor FPV.

Penggunaan OSD dengan sistem FPV pada tugas akhir ini akan membahas tentang perancangan dan pengembangan OSD dengan penambahan beberapa fitur menu seperti data sensor Ultrasonik, data temperatur, posisi lengan robot, level battery dan RTC (Real Time Clock) yang diaplikasikan pada Semi Autonomous Mobile Robot dengan lengan untuk pengambilan sebuah objek. OSD yang dipakai nantinya akan menggunakan minimOSD yang diprogram dengan kontroler Arduino. Pada minimOSD ini dilakukan sebuah penambahan pin wiring untuk proses pembacaan sensor temperatur, RTC dan level battery. Selain itu, untuk beberapa sensor seperti sensor Ultrasonik dan lengan robot dikonfigurasikan dengan Arduino yang ada pada mobile robot tersebut. Untuk data GPS (Global Positioning System) sendiri, menggunakan modul APM (ArduPilot Mega) yang nantinya akan dikombinasikan dengan data-data sensor extra wires pada minimosd dan ditransmisikan bersama data visual kamera menggunakan sistem FPV menuju layar monitor FPV.

\section{OSD DENGAN SISTEM FPV}

OSD merupakan sebuah display menu konfigurasi yang ditampilkan pada sebuah layar monitor. Tetapi pada dunia robotika, OSD digunakan untuk menampilkan beberapa kumpulan data secara live streaming yang dikirm menggunakan sistem FPV yakni menggunakan pengiriman Video Transmitter. Tipe OSD yang digunakan adalah MinimOSD.[1]

Minimosd biasanya digunakan pada beberapa robot tanpa awak seperti pada drone, pesawat UAV, atau pada mobile robot. Menggunakan Minimosd dikarenakan bentuk hardware yang kecil dan minimalis, tidak terlalu memakan ruang jika diaplikasikan pada mobile robot. Sedangkan sebuah sistem FPV (First Person View) yang juga dikenal sebagai Remote Person View (RPV), atau piloting dengan video, adalah metode yang digunakan untuk mengontrol kendaraan remote control dari driver atau pilot view point. Paling sering digunakan untuk pilot pesawat radio kontrol atau jenis lain dari kendaraan udara tak berawak (UAV).[2] 


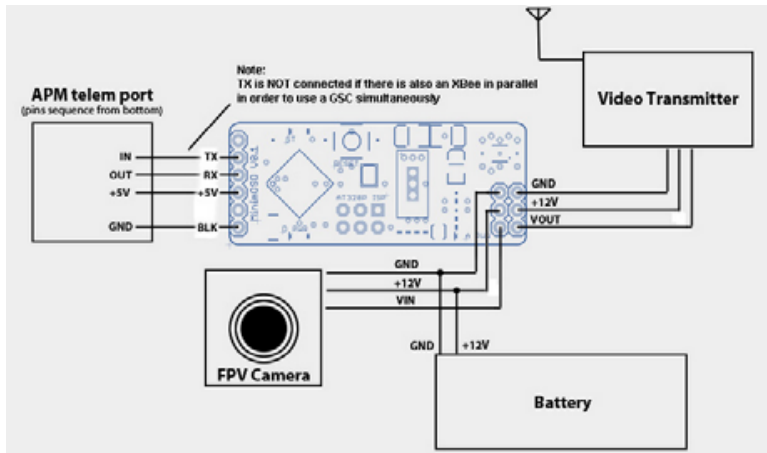

Gambar 1. Wiring Diagram Minimosd dengan Sistem FPV[3]

\section{PERANCANGAN SISTEM}

\section{A. Digaram Blok Sistem Keseluruhan}

Diagram blok pada Gambar 2 di bawah ini menunjukkan alur kerja keseluruhan dari sistem pengembangan OSD dengan penambahan menu yang diaplikasikan pada semi autonomous mobile robot. Sesuai dengan alur diagram blok pada Gambar 2, cara kerja dari sistem ini menggunakan beberapa mikrokontroler untuk mendukung beberapa fitur menu sensor yang akan ditampilkan pada layar monitor FPV.

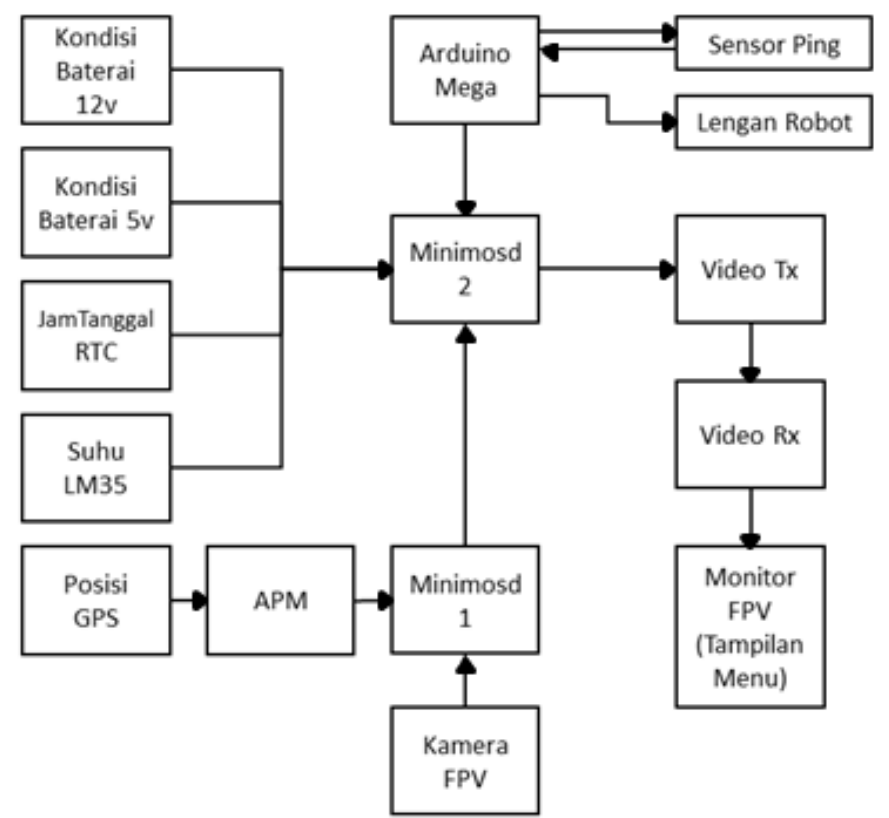

Gambar 2. Diagram blok sistem keseluruhan

\section{B. Perancangan Hardware}

Perancangan hardware pengembangan osd ini dengan melakukan penambahan pengkabelan pada minimosd, serta melakukan penggabungan fungsi beberapa komponen seperti sensor suhu, RTC, baterai, GPS, konfigurasi minimosd dengan Arduino Mega, konfigurasi dengan APM serta kamera FPV.

\section{Perancangan Pengkabelan Minimosd 1}

Pada minimosd yang pertama dilakukan perancangan pengkabelan dengan mengkonfigurasi modul APM yang mengambil data dari GPS 3DR Ublox, setelah itu dikirm ke minimosd 1 untuk diproses kedalam bentuk data visual. Pada minimosd 1 ini diprogram dengan memanfaatkan platform yang sudah tersedia di google yakni menggunakan software minimosd extra. Berikut pada Gambar 3 merupakan rancangan pengkabelan dari minimosd pertama.

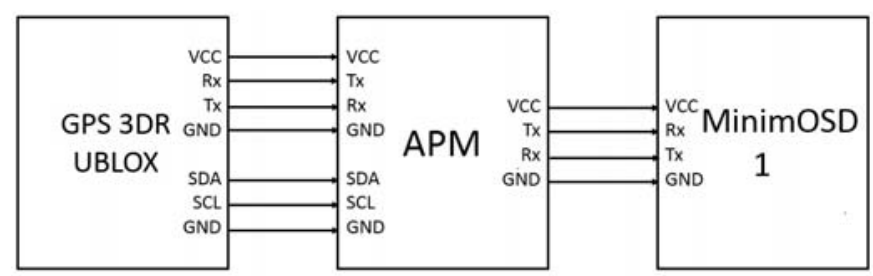

Gambar 3. Wiring Minimosd 1

\section{Perancangan Extra Wires Minimosd 2}

Pada minimosd hanya terdapat kaki pin Tx dan Rx sebagai penerima data dari luar. Maka dari itu dilakukan penambahan extra wires pada pin ATMega328.

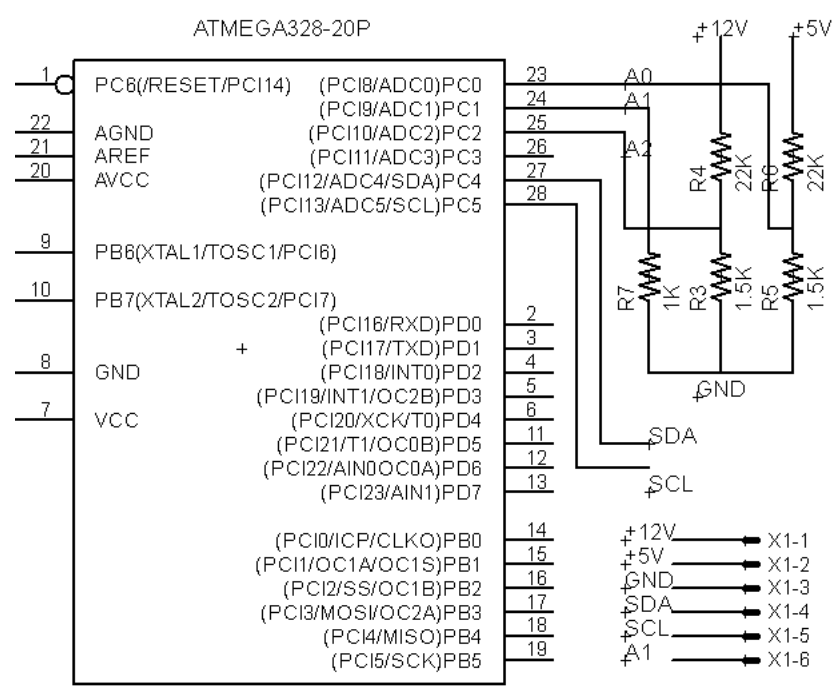

Gambar 4. Wiring Minimosd 2

Dan berikut terlihat pada Tabel 1 keterangan pin dari gambar tersebut.

Tabel 1. Konfigurasi Pin Minimosd 1

\begin{tabular}{cccc}
\hline $\begin{array}{c}\text { Pin ATMega } \\
\mathbf{3 2 8}\end{array}$ & Pin Arduino & Fungsi & Ket. \\
\hline PORTC.0 & A0 & ADC & $\begin{array}{c}\text { Baterai } \\
12 \mathrm{v}\end{array}$ \\
PORTC.1 & A1 & ADC & LM35 \\
PORTC. 2 & A2 & ADC & Baterai 5v \\
PORTC. 4 & A4 & SDA & RTC \\
PORTC.5 & A5 & SCL & \\
\hline \hline
\end{tabular}

\section{E. Perancangan Baterai dan Program ADC}

Untuk mengetahui dan memonitoring tegangan baterai yang bekerja pada sistem mobile robot agar tidak terjadi kehabisan baterai saat proses kerja, maka dilakukan pengambilan data baterai sistem dengan menggunakan pembacaan ADC (Analog to Digital Converter). Pengkabelan baterai ini dengan menggunakan extra wires yang terhubung dengan pin A0 dan A2 seperti yang telah diulas sebelumnya. 


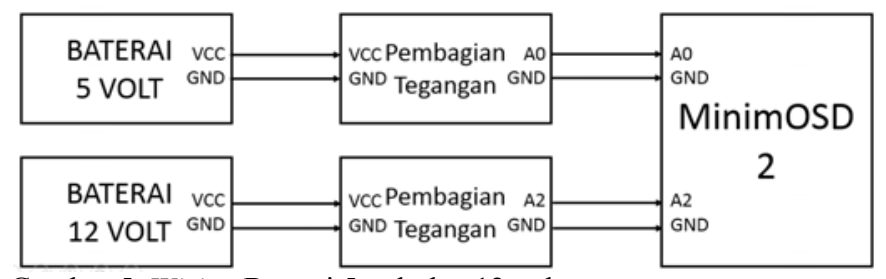

Gambar 5. Wiring Baterai 5 volt dan 12 volt

Rumus yang digunakan untuk pemrograman ADC didapat dari kombinasi perhitungan pembagian tegangan dan pembacaan ADC. Berikut rumus dasar dari perhitungan tersebut:

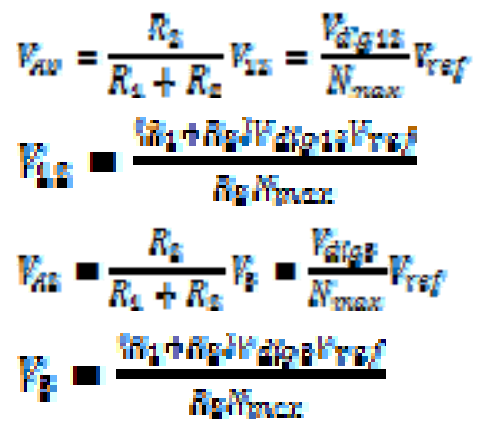

Dan berikut pada Tabel 2 merupakan simbol-simbol yang akan ditampilkan utnuk menunjukkan level baterai.

\begin{tabular}{ccc} 
& Tabel 2. Display Level Baterai \\
\hline \hline Simbol & Level (volt) & Keterangan \\
\hline & $9.5 \leq \mathrm{V}<10$ & Baterai Kosong \\
\hline & $10 \leq \mathrm{V}<10.5$ & Hampir Habis \\
& $10.5 \leq \mathrm{V}<11$ & Baterai $25 \%$ \\
& $11.5 \leq \mathrm{V}<11.5$ & Baterai $75 \%$ \\
\hline
\end{tabular}

\section{F. Perancangan Rangkaian RTC dan Program I2C}

Untuk rangkaian RTC ini menggunakan modul RTC Arduino DS1307 24C32. Pada minimosd tidak ada tempat untuk pin SDA dan SCL, maka sama halnya untuk rancangan baterai, disini dilakukan penambahan pengkabelan pada pin PORTC.4 dan PORTC.5 sebagai masukan data dan clock pada ATMega 328.

Untuk perancangan program RTC (Real Time Clock) menggunakan metode pengiriman $\mathrm{I} 2 \mathrm{C}$ (Inter Integrated Circuit) yang menggunakan library yang sudah tersedia dan dapat didownload di web resmi Arduino.

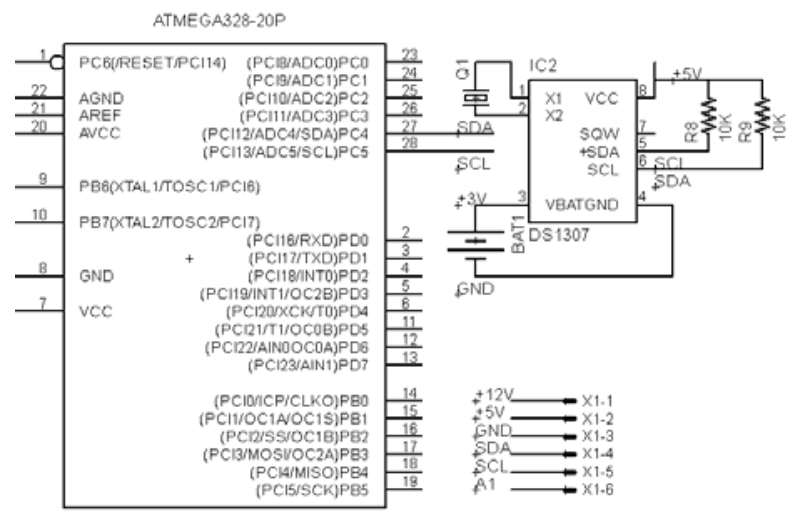

Gambar 6. Wiring RTC

\section{G. Perancangan Rangkaian LM35 dan Program ADC}

Penambahan pengkabelan pada minimosd juga dilakukan untuk sensor suhu LM35 ini. Sensor suhu atau temperatur yang dipasang pada mobile robot ini berguna untuk mengetahui kondisi sekitar mobile robot dalam keadaan panas atau dingin.

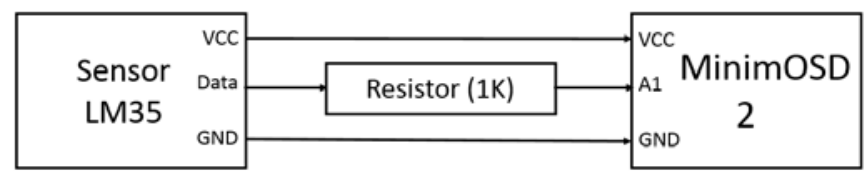

Gambar 7. Wiring LM35

Program LM35 didapat dari hasil kalkulasi antara tegangan output sensor setiap kenaikan $1{ }^{\circ} \mathrm{C}$ dengan nilai bit data mikro. Berikut merupakan perumusannya.

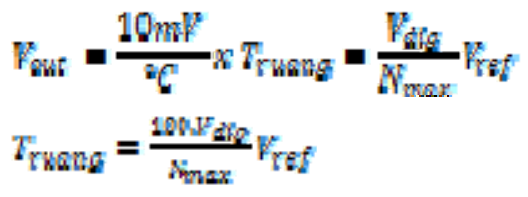

\section{H. Perancangan Komunikasi Serial Mega dengan Minimosd}

Arduino Mega yang merupakan otak dari mobile robot disini digunakan untuk mengambil data sensor ultrasonik dan memberikan instruksi pada lengan robot. Data sensor ultrasonik dan posisi lengan robot yang didapat oleh Arduino Mega berupa jarak robot dengan sebuah objek nantinya akan dikirim ke minimosd 2 menggunakan pengiriman komunikasi serial TTL.

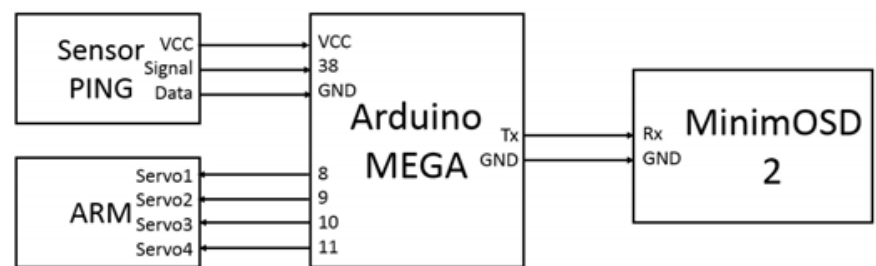

Gambar 8. Wiring Arduino Mega dan Minimosd

Untuk posisi lengan robot yang berupa sudut yang diterima oleh Minimosd akan dibagi dengan 9. Angka 9 tersebut menunjukkan adanya 10 bagian simbol yang akan digambarkan. Berikut pada Tabel 3 merupakan gambar dan penjelasan dari 10 bagian gambar tersebut. 
Tabel 3. Display Posisi Lengan Robot

\begin{tabular}{|c|c|}
\hline Simbo & Sudut $\left({ }^{\circ}\right)$ \\
\hline & $0-9$ \\
\hline & $10-18$ \\
\hline & $19-27$ \\
\hline- & $28-36$ \\
\hline - & $37-45$ \\
\hline - & $46-54$ \\
\hline F & $55-63$ \\
\hline - & $64-72$ \\
\hline & $72-81$ \\
\hline & $82-90$ \\
\hline
\end{tabular}

\section{Perancangan Kombinasi Minimosd dan Sistem FPV}

Pada tahap ini dilakukan sebuah perancangan kombinasi 2 (dua) minimosd dan penggabungan data visual kamera $\mathrm{AV}$ dengan data visual minimosd, yang setelahnya dikirim menggunakan video transmitter menuju video receiver untuk ditampilkan pada layar monitor FPV.

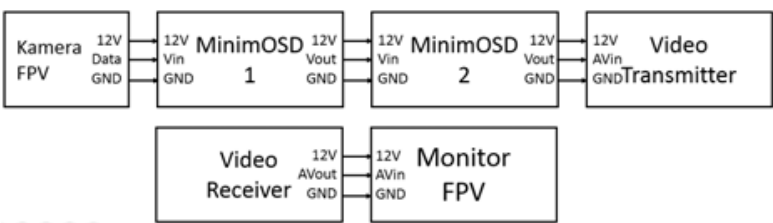

Gambar 9. Wiring Kombinasi Minimosd dan Sistem FPV

\section{J. Flowchart Program Arduino}

Pada tahapan ini menjelaskan bagaimana alur kerja program Arduino berjalan yang digambarkan dengan flowchart. Terlihat pada Gambar 10 program diawali dengan inisialisasi atau deklarasi variabel, tujuannya untuk mempermudah dalam proses kerja program tersebut.

\section{K. Perancangan Tampilan Layar}

Perancangan untuk proses pengkonversian data-data sensor menjadi sebuah karakter ini menggunakan IC Max7456 yang hanya mempunyai 256 data karakter saja.

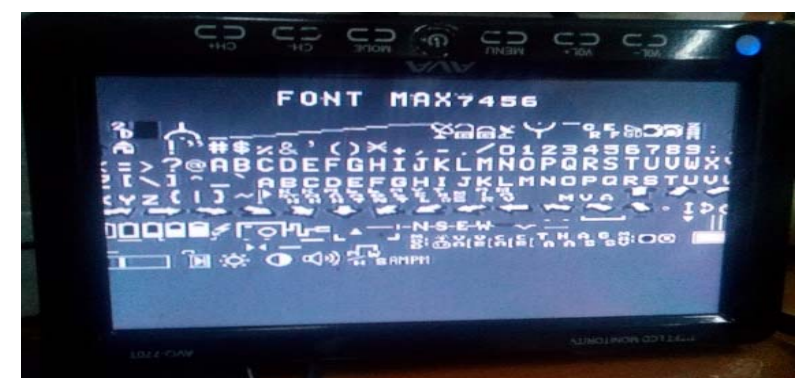

Gambar 11. Simbol Minimosd

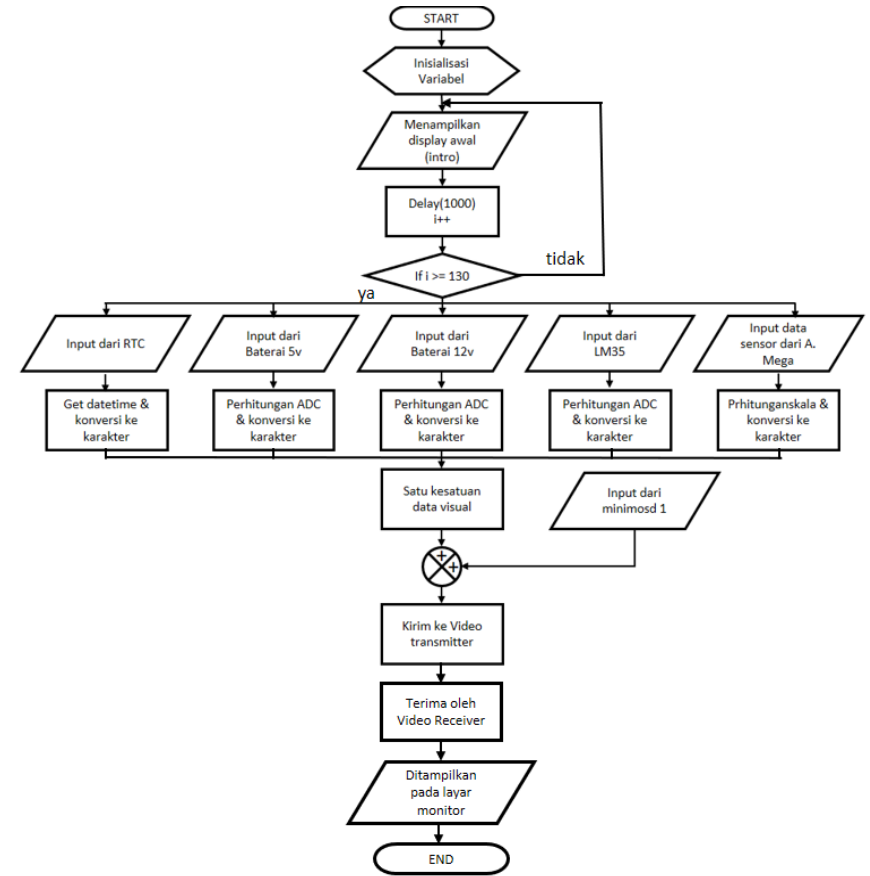

Gambar 10. Flowchart Program Arduino

Tampilan layar berukuran 30x15, perancangan tampilan menu-menu sensor dijadikan satu kesatuan dengan koordinat posisi yang sudah ditentukan.

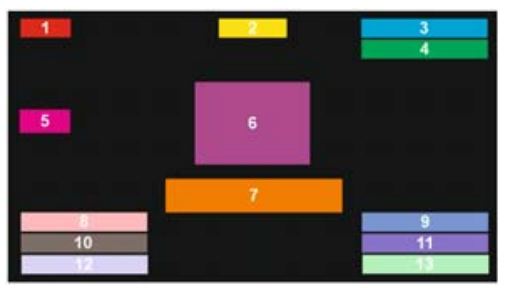

Gambar 12. Display Menu

Keterangan:

1. Satelit

2. Heading Kompas / Derajat Mata Angin

3. Tanggal, Bulan, dan Tahun

4. Jam, Menit, dan Detik

5. Kecepatan

6. Posisi Lengan Robot

7. Jarak / Ultrasonik

8. Altitude

9. Temperatur

10. Latitude

11. Baterai 5 volt

12. Longitude

13. Baterai 12 volt

\section{PENGUJIAN SISTEM}

\section{A. Implementasi Pengembangan Minimosd}

Pada tahap pengimplementasian pengembangan Minimosd ini yakni merealisasikan sebuah sistem menjadi sebuah bentuk produk sesuai dengan hasil perancangan hardware dan software yang telah dijelaskan sebelumnya. Dan berikut pada Gambar 13 merupakan bentuk jadi produk yang telah dibuat. 


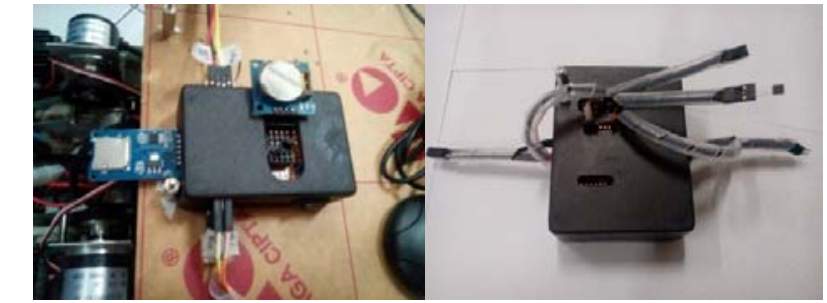

Gambar 13. Produk Minimosd

Berikut implementasi alat untuk digunakan pada Semi Autonomous Mobile Robot sesuai dengan judul tugas akhir yang telah disusun ini. Dan berikut peletakan alat seperti pada Gambar 14.
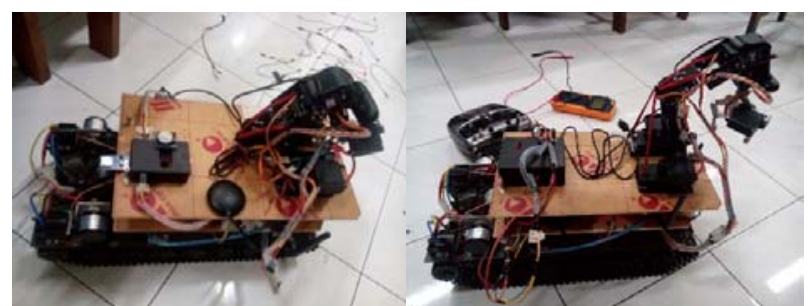

Gambar 14. Implementasi Produk pada Mobile Robot

Realisasi software berupa tampilan display awal dan tampilan menu yang sebelumnya telah dilakukan perancangan. Realisasi software seperti pada Gambar 15 dibawah ini.

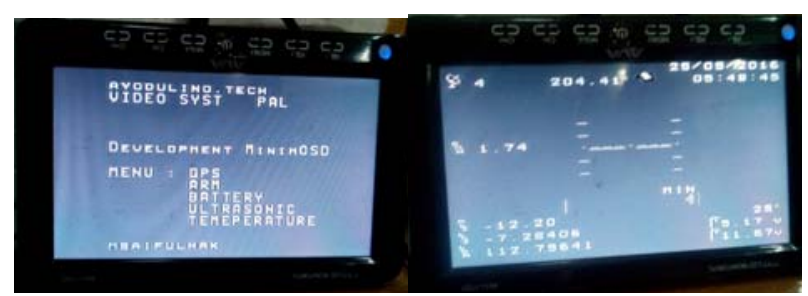

Gambar 15. Tampilan Awal dan Menu pada Layar Monitor

\section{B. Pengujian Data pada Minimosd 1}

Pada tahap ini dilakukan sebuah pengujian beberapa data yang terdapat pada Minimosd 1 guna mengetahui akurasi dari pembacaan yang nantinya sebagai informasi data yang sangat penting bagi driver robot atau pengendali robot, beberapa data tersebut antara lain tegangan baterai 5 volt dan 12 volt, data sensor suhu LM35, RTC, dan juga data serial berupa data sensor ultrasonik dan posisi lengan robot yang dikirim oleh Arduino Mega. Berikut pada Gambar 16 merupakan grafik dari hasil pengujian data baterai 5 volt dan 12 volt.
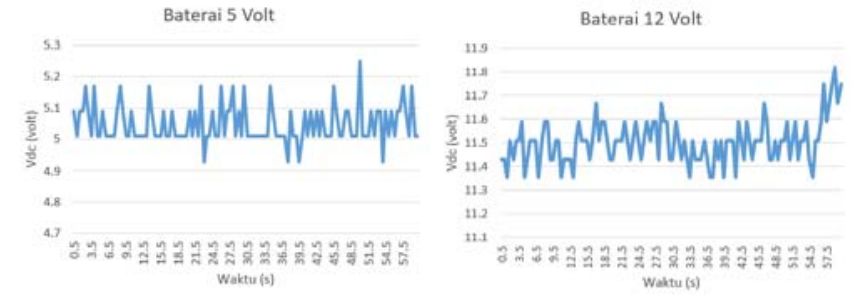

Gambar 16. Grafik Baterai 5 Volt dan 12 Volt

Dan berikut pada Gambar 17 merupakan hasil dari pengujian sensor LM35 tersebut.

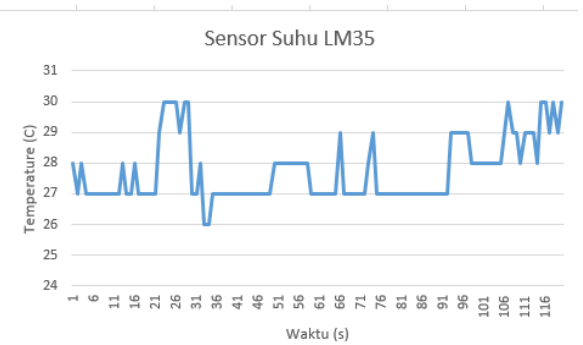

Gambar 17. Grafik Sensor Suhu LM35

Sedangkan untuk waktu dan tanggal diambil dari rangkaian RTC dengan pengiriman I2C, berikut pada Gambar 18 hasil pengujiannya yang ditampilkan pada layar monitor.

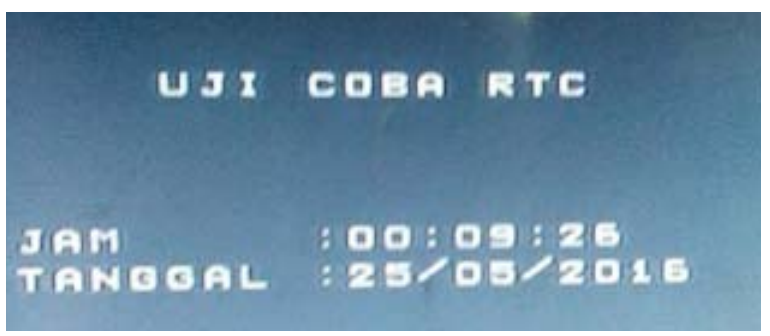

Gambar 18. Uji Coba RTC

Untuk pengujian serial terdapat dua pengujian data yang meliputi pengujian animasi sensor ultrasonik dan pengujian posisi lengan robot. Berikut pada Tabel 4 merupakan animasi penggambaran jarak yang dibaca oleh sesnsor ultrasonik dengan skala perbandingan 1:30.

\begin{tabular}{|c|c|c|}
\hline \multicolumn{2}{|r|}{ Animasi } & \multirow{2}{*}{$\begin{array}{c}\text { Jarak (cm) } \\
0-29\end{array}$} \\
\hline $1=0$ & CM MID & \\
\hline $133 c$ & 4) -1 & $30-59$ \\
\hline 776 & SM & $60-89$ \\
\hline 102 & CII & $90-119$ \\
\hline $1^{130}$ & $\mathrm{CH}$ & $120-149$ \\
\hline 169 & $6 y$ & $150-179$ \\
\hline 194 & C) & $180-209$ \\
\hline 239 & $\mathrm{EM}$ & $210-239$ \\
\hline 250 & $\mathrm{CM}$ & $240-269$ \\
\hline $1^{288}$ & $\mathrm{CM}$ & $270-299$ \\
\hline (15) 20 & CM MAX & $>300$ \\
\hline
\end{tabular}

Sedangkan untuk penggambaran posisi lengan robot dilakukann dengan skala perbandingan 1:9. Berikut pada Tabel 5 merupakan hasil dari pengskalaan tersebut.

Tabel 5.

Uji Posisi Lengan Robot 


\begin{tabular}{|c|c|}
\hline Animasi & Sudut $\left({ }^{\circ} \mathbf{C}\right)$ \\
\hline & $0-89$ \\
\hline & $90-179$ \\
\hline
\end{tabular}

\section{Pengujian Data pada Minimosd 2}

Pada tahap ini dilakukan pengujian data GPS oleh Minimosd 2 yang diperoleh dari ArduPilot Mega. Berikut pada Gambar 19 merupakan hasil dari pengujian tersebut.

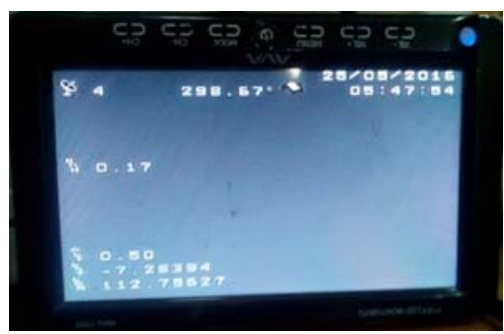

Gambar 19. Uji Coba Data APM

\section{Pengujian pada Mobile Robot}

Pada tahap pengujian pengembangan Minimosd dengan penambahan beberapa menu sensor yang diaplikasikan pada mobile robot didapatkan data display awal seperti pada gambar 20 berikut ini.

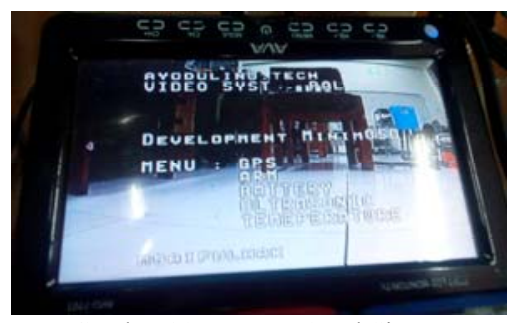

Gambar 20. Display Awal Sistem

Dan untuk display menu terdiri dari beberapa menu sensor yang dijadikan menjadi satu kesatuan data visual, yang meliputi data GPS (longitude, latitude, altitude, satelit, kecepatan, kompas), RTC, sensor temperatur atau suhu, level baterai 5 volt dan 12 volt, data sensor ultrasonik dan posisi lengan robot. Data hasil pengujian pada mobile robot dapat dilihat seperti pada Gambar 21.

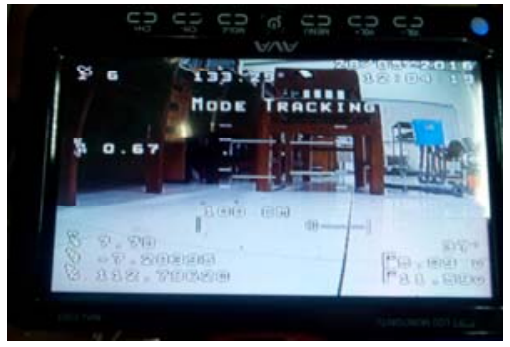

Gambar 21. Display Menu

\section{KESIMPULAN}

Berdasarkan data hasil uji pengembangan Minimosd dengan penambahan menu untuk diaplikasikan pada mobile robot ini diperoleh beberapa kesimpulan antara lain dalam pengembangan Minimosd ini menggunakan dua Minimosd untuk melengkapi beberapa menu sensor yang tidak tersedia di ArduPilot Mega, dilakukan extra wiring pada Minimosd oleh karena pin input yang tersedia hanya Tx dan Rx, terbatasnya memori dari ATMega 328 jika Minimosd ini dikembangkan menjadi sebuah sistem ArduPilot mini, serta penggambaran animasi lengan robot hanya dapat dilakukan dengan pengembangan 256 data karakter saja sehingga animasi tidak bisa digambarkan sesuai dengan bentuk real.

\section{DAFTAR PUSTAKA}

[1] ArduPilot Dev Team, "Minim OSD Quick Installation Guide”, 2012.

[2] Oscar (2013). Program MinimOSD using Arduino without FTDI Cable. USA.

[3] Windestal, David, “The FPV Starting Guide", RCExplorer, 2 Juni 2013.

[4] Marsono, Cara Kerja OSD (On Screen Display), diakses pada tanggal 12 Maret 2016, http://marsonotv.co..id/2011/10/cara-kerja-osd-on-screendisplay.html.

[5] Arduino Founder, Introduction of Arduino, diakses pada tanggal 1 Maret 2016, https://www.arduino.cc/en/Guide/Introduction 